\title{
Characterization of Nanocellulose Obtained from Cereus Forbesii (a South American cactus)
}

\author{
Camilo Orrabalis ${ }^{a}$, Daniela Rodríguez $z^{a}$,Laura G. Pampillo ${ }^{b}$,Cesar Londoño-Calderón ${ }^{c}$,
}

\author{
Mariel Trinidad ${ }^{a}$ Ricardo Martínez-García ${ }^{b *}$ (i) \\ ${ }^{a}$ Universidad Nacional de Formosa, Facultad de Recursos Naturales, Campus Universitario, Modulo I, \\ Av. Gutnisky 3200, Formosa, Argentina \\ ${ }^{b}$ Universidad de Buenos Aires, Instituto de Tecnología y Ciencias de la Ingeniería. "Hilario Fernández \\ Long", Facultad de Ingeniaría, CP 1063, Buenos Aires, Argentina \\ c Universidad de Buenos Aires, Instituto de Tecnología de Polimeros y Nanotecnología (ITPN), CP \\ 1127, Buenos Aires, Argentina
}

Received: March 15, 2019; Revised: August 11, 2019; Accepted: November 28, 2019

\begin{abstract}
Crystalline cellulose nanofibers are obtained from the bark of Cereus Forbesii, a cactus native to the arid areas of South America. The obtaining of cellulose nanofibers was carried out in several steps: pretreatment of the raw material, elimination of hemicellulose and lignin to obtain cellulose, and an acid hydrolysis of cellulose to obtain crystalline cellulose nanofibers. The cellulose nanofibers obtained have a crystallinity index of $82 \%$ and a nanofiber diameter of $18 \mathrm{~nm}$. An average crystallite size of 6 $\mathrm{nm}$ was calculated for the crystalline domains that form cellulose nanofibers. The high crystallinity of the obtained cellulose nanofibers makes the sample very homogeneous and decomposes in a relatively narrow temperature range (between $290^{\circ} \mathrm{C}$ and $375^{\circ} \mathrm{C}$ ). The complete degradation of crystalline cellulose polymer chains takes place between $375^{\circ} \mathrm{C}$ and $600^{\circ} \mathrm{C}$. The morphological and structural studies are carried out by scanning electron microscopy of field emission, infrared spectrometry with Fourier transform, and powder X-ray diffraction. The thermal stability of the samples is determined by thermogravimetric analysis.
\end{abstract}

Keywords: Nanocellulose, cellulose nanofibers, crystalline cellulose, cactus, Cereus Forbesii

\section{Introduction}

Cellulose obtained from natural sources has been used by man in many applications for centuries. The development in materials engineering has allowed us to add new uses of cellulose. Cellulose is not only used in the traditional way, it is also used in the form of nanostructured material. For example, cellulose is used as constituent part of composite materials ${ }^{1-8}$ in fields such as biomedicine ${ }^{9}$, separation of heavy materials ${ }^{10,11}$, electronic devices ${ }^{12}$, photovoltaic cells ${ }^{13}$, reinforcement materials ${ }^{14}$, etc. Nanocellulose provides mechanical strength, low density, and a reactive surface formed by $\mathrm{OH}^{-}$groups that allow surface functionalization ${ }^{3}$.

There are two kinds of nanocellulose: cellulose nanocrystals (CNC), and crystalline cellulose nanofibers (CNF) ${ }^{15}$. The production of CNF from plants has increased considerably in the last years ${ }^{16-18}$. Its method of obtaining is relatively simple. The fibers of the plants are formed mainly by cellulose, hemicellulose and lignin. Cellulose is ordered in the form of fibers encapsulated by other non-cellulosic components of the plant cell wall ${ }^{19-22}$. Such cellulose fibers are formed by amorphous regions and monocrystalline domains ${ }^{23}$. Both components, amorphous and crystalline, can be separated by controlled acid hydrolysis.

Many vegetal sources of cellulose nanofibers have been studied; for example, the Agave Angustifolia ${ }^{24}$, the cotton ${ }^{25}$,

*e-mail: rmartinez@fi.uba.ar pulp of sugar beet ${ }^{26}$, flax ${ }^{27}$, the rice husk ${ }^{28}$, wheat straw ${ }^{29-31}$, potato ${ }^{32}$, banana ${ }^{33}$, and sisal fibers ${ }^{34,35}$. However, as far as we know, no variety of cactus has been studied.

In this manuscript we report the obtaining of crystalline cellulose nanofibers from the bark of Cereus Forbesii, a cactus native to arid areas of South America. This cactus belongs to the Cactaceae family, and is one of the thirtythree large columnar cacti species of South America (see figure 1). There are some studies on cacti of the Cactaceae family ${ }^{36-38}$, but, as far as we know, this is the first report on obtaining nanocellulose from a cactus. In this paper, we perform the structural characterization and thermal stability determination of crystalline cellulose nanofibers obtained from the Cereus Forbesii bark. To carry out the obtaining of cellulose nanofibers, a method based on consecutive treatments of alkaline hydrolysis and acid hydrolysis is used, which allows us to obtain cellulose nanofibers with a crystallinity index of $82 \%$ and a nanofiber diameter of $18 \mathrm{~nm}$.

\section{Materials and Methods}

\subsection{Raw material}

The bark of the Cereus Forbesii cactus was obtained from the central-western region of the province of Formosa, Argentina. The bark was separated from the pulp by hand. After that, the bark was washed with distilled water and dried 


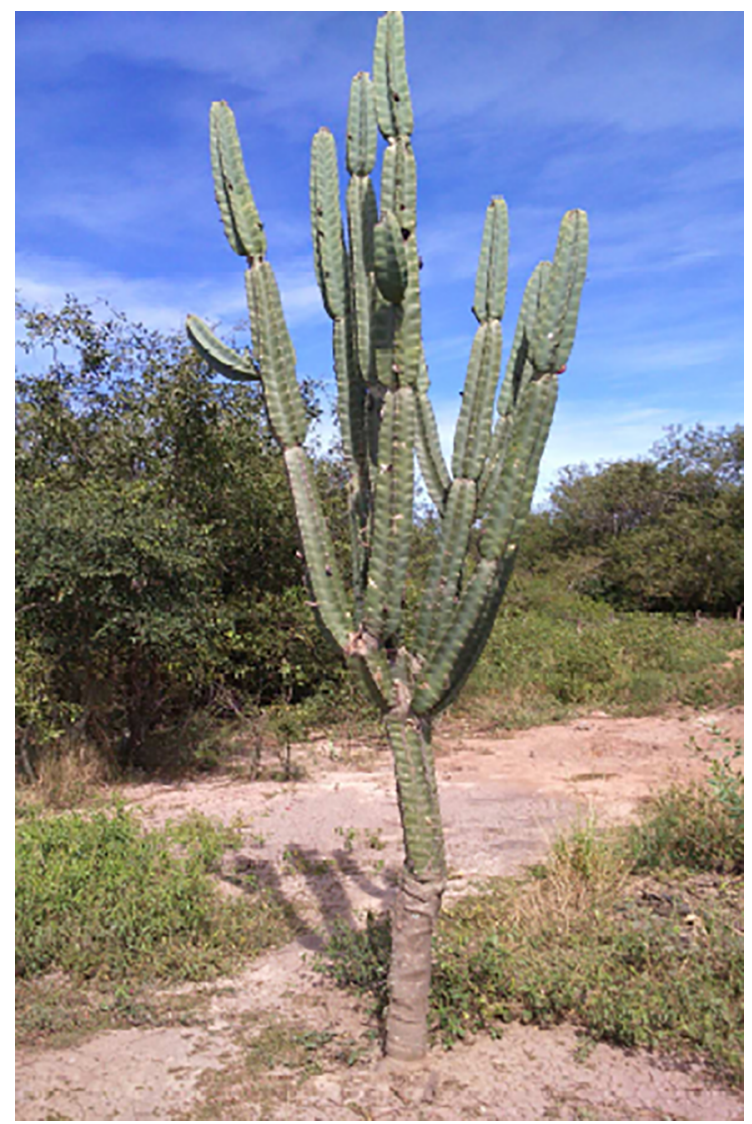

Figure 1. Photograph of the Cereus Forbesii, native cactus of arid regions of South America.

at $80^{\circ} \mathrm{C}$ for 8 hours. The dehydrated bark was milled at 2400 rpm using a Universal High Speed Disintegrator FW100 (0.46 $\mathrm{kW}, 24000 \mathrm{rpm}, 220 \mathrm{~V}, 50 \mathrm{~Hz})$. A powder with a fine fraction of MESH 60 (average particle size of $250 \mu \mathrm{m}$ ) was obtained and used as raw material. Successive chemical treatments were applied to this raw material to remove minerals, lignin, hemicellulose, and obtain crystalline cellulose ${ }^{39-43}$.

Moisture, extractives, ash, lignin (acid soluble and insoluble lignin), cellulose and hemicellulose content in the raw material were estimated following NREL laboratory analytical procedures ${ }^{44-47}$. The concentration of sugars was determined by HPLC. The detector was based on the refractive index measurement. An amino 250x4.6 mm Grace Inc. column was used and acetonitrile: water 70:30 was the mobile phase at a flow rate of $1.2 \mathrm{ml} / \mathrm{min}$ and isocratic conditions. All samples were centrifuged at $5000 \mathrm{rpm}$ for 5 minutes and filtered before analysis. The lignocellulosic composition of the Cereus Forbesii bark is reported in Table 1. A comparison with other lignocellulosic materials is shown in Table 2 .

\subsection{Obtaining cellulose nanofibers}

The milled Cereus Forbesii bark was chemically treated to obtain crystalline cellulose nanofibers. The chemical
Table 1. Lignocellulosic composition of the Cereus Forbesii bark.

\begin{tabular}{lc}
\hline Component & $\begin{array}{c}\text { Content (\% w/w) dry } \\
\text { biomass }\end{array}$ \\
\hline Moisture & $7.50 \pm 0.20$ \\
Lignin (total content) & $16.81 \pm 3.79$ \\
Cellulose & $32.62 \pm 2.37$ \\
Hemicellulose (Xylan included) & $20.01 \pm 1.91$ \\
Ash & $10.40 \pm 0.90$ \\
Extractives & $12.60 \pm 1.50$ \\
\hline
\end{tabular}

method used is based on the methods reported to extract cellulose from other plant raw materials ${ }^{25,28,35}$. Two cycles of alkaline and acid treatments are performed. In the first cycle, the raw lignocellulosic mass is treated to remove minerals and lignin. In the second cycle, the elimination of non-soluble lignin and hemicellulose is completed and the amorphous component of cellulose is removed.

The first cycle of alkaline and acid treatments begins when the raw material is treated at room temperature with an aqueous solution of potassium hydroxide (3\% w/v) in a ratio of $1: 12 \mathrm{~g} / \mathrm{ml}$. The sample was stirred for 5 minutes and boiled for 30 minutes. Thereafter, the material was left overnight at room temperature, and a precipitate was obtained. This solid was filtered and washed with distilled water until a neutral $\mathrm{pH}$ was reached. The filtered solid was washed with an aqueous solution of hydrochloric acid (10\% $\mathrm{v} / \mathrm{v})$ at room temperature. The remaining solid was treated with $0.7 \%(\mathrm{w} / \mathrm{v})$ sodium chlorite in a ratio of $1: 50 \mathrm{~g} / \mathrm{ml}$ at $\mathrm{pH} 4$ and boiled for 2 hours. After that, an aqueous solution of sodium bisulfate $(5 \% \mathrm{w} / \mathrm{v})$ in a ratio of $1: 50 \mathrm{~g} / \mathrm{ml}$ was added to the solid obtained, and kept for 1 hour at room temperature. The sample was washed with distilled water to reach a $\mathrm{pH}$ of $6-7$, and dried at $80^{\circ} \mathrm{C}$ in the oven. The second cycle begins when the remaining solid is treated with an aqueous solution of sodium hydroxide $(17.5 \% \mathrm{w} / \mathrm{v})$ in a ratio of $1: 50 \mathrm{~g} / \mathrm{ml}$ at room temperature for 8 hours, washed and dried at $80^{\circ} \mathrm{C}$. At this point a solid rich in cellulose was obtained. Such solid was treated with an aqueous solution of sulfuric acid $(60 \% \mathrm{w} / \mathrm{w})$ in a ratio of $1: 12 \mathrm{~g} / \mathrm{ml}$ for 30 minutes with stirring at room temperature, washed with distilled water until reaching a neutral $\mathrm{pH}$, and dried at $80^{\circ} \mathrm{C}$ to obtain the crystalline cellulose nanofibers.

\subsection{Characterization methods}

Fourier transform infrared characterization (FTIR) was performed using a Shimadzu IR Affinity-1 spectrometer. The samples were dried and pelletized using $\operatorname{KBr}(1: 100 \mathrm{w} / \mathrm{w})$. The spectra were recorded in a range of $4200 \mathrm{~cm}^{-1}$ to $500 \mathrm{~cm}^{-1}$ with a resolution of $2 \mathrm{~cm}^{-1}$. Cereus Forbesii bark samples (raw and chemically treated) were coated with a thin layer of gold using an ion sputter coater, and their morphology were analyzed with a Field Emission Scanning Electron Microscope (FESEM, Zeiss Supra 40) with field emission gun operated at $3 \mathrm{kV}$. X-ray 
Table 2. Lignocellulosic composition of some lignocellulosic materials.

\begin{tabular}{|c|c|c|c|c|}
\hline Material & Cellulose $(\% w / w)$ & Xylan or Hemicellulose $(\% \mathrm{w} / \mathrm{w})$ & Lignin $(\% \mathrm{w} / \mathrm{w})$ & Reference \\
\hline Pine spp. & & $\begin{array}{l}\text { Carbohydrates } \\
65.17 \pm 0.74\end{array}$ & $24.45 \pm 1.31$ & 48 \\
\hline Eucalyptus spp. & & $\begin{array}{c}\text { Carbohydrates } \\
69.9 \pm 2.11\end{array}$ & $12.01 \pm 0.93$ & 48 \\
\hline Eucalyptus obliqua & $25.77 \pm 10$ & Hemicellulose $8.25 \pm 1.00$ & $43.30 \pm 30$ & 49 \\
\hline Corn Stover & 33.20 & $\begin{array}{l}\text { Xylan } \\
22.34\end{array}$ & 16.49 & 50 \\
\hline Elephant grass & $34.41 \pm 0.96$ & $\begin{array}{c}\text { Xylan } \\
18.49 \pm 1.05\end{array}$ & $16.60 \pm 0.42$ & 51 \\
\hline Opuntia ficus indica & $31.60 \pm 2.30$ & Hemicellulose $17.1 \pm 1.2$ & $10.3 \pm 0.5$ & 52 \\
\hline Nopalea cochenillifera & $34.9 \pm 0.3$ & Hemicellulose $20.0 \pm 1.3$ & $15.7 \pm 0.2$ & 52 \\
\hline
\end{tabular}

powder diffraction patterns $(\mathrm{XRD})$ were recorded on a Rigaku diffractometer with $\mathrm{Cu} \mathrm{K} \alpha(\lambda=0.1541 \mathrm{~nm})$ radiation in a range of $10^{\circ}$ to $100^{\circ}$. The crystallinity index (Ic) of the samples were calculated using the peak height method ${ }^{53,54}$. The size of the crystallites (D) that form the crystalline cellulose nanofibers was estimated using the Scherrer equation ${ }^{55}$. Thermogravimetric analysis (TGA) was performed on a Shimadzu TGA-50 instrument. The temperature program was run from $25^{\circ} \mathrm{C}$ to $650{ }^{\circ} \mathrm{C}$ at a heating rate of $10^{\circ} \mathrm{C} / \mathrm{min}$ under a nitrogen atmosphere $(30 \mathrm{ml} /$ $\mathrm{min}$ ) to avoid thermoxidative degradation.

\section{Results and Discussion}

\subsection{Scanning Electron Microscopy}

The FESEM micrographs corresponding to the raw and chemical treated samples appear in Figure 2. Figure 2 a shows the morphology of the milled raw bark on a nanometric scale. This sample has a rough surface with a large surface area that maximizes the chemical reactivity of the sample. This aspect is important for the efficiency of subsequent chemical treatment.

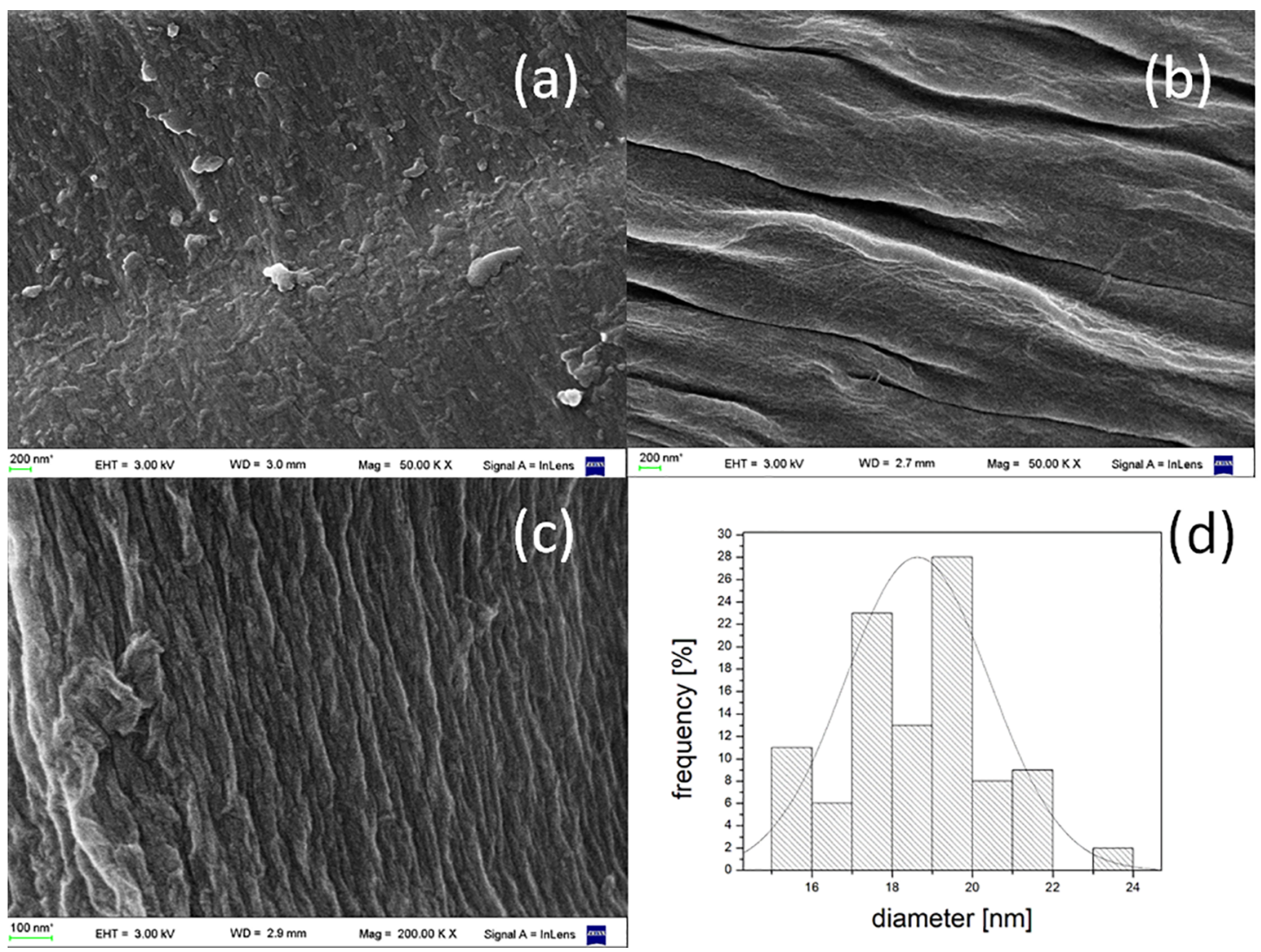

Figure 2. FESEM micrographs of: Cereus Forbesii bark (a), cellulose obtained by alkaline treatment (b), cellulose nanofibers obtained by the acid hydrolysis of cellulose (c), and diameters distribution of cellulose nanofibers (d). 
The morphology of the cactus bark changes after the alkaline chemical treatment (see Figures $2 \mathrm{a}$ and $2 \mathrm{~b}$ ). Bundles of cellulose fibers appear when lignin and hemicellulose are removed. In addition, a less rough surface is formed (figure $2 b$ ). A second step of the chemical treatment is the acid hydrolysis of cellulose. This process produces the crystalline cellulose nanofibers shown in figure $2 \mathrm{c}$. The nanocellulose is obtained when the action of the acid decomposes the amorphous regions of the cellulose. These regions are structurally more disordered than the crystalline regions, and less energy is required for their decomposition. Figure 2d shows the histogram corresponding to the diameters of crystalline cellulose nanofibers. The distribution of nanofiber diameters is between $15 \mathrm{~nm}$ and $23 \mathrm{~nm}$, and the average nanofiber diameter is $18 \mathrm{~nm}$. These results are similar to those reported for nanofibers obtained from other plants. For example, nanofibers with an average diameter of $12 \mathrm{~nm}$ are obtained from cotton ${ }^{25}$, and nanofibers with diameters between $8 \mathrm{~nm}$ and $15 \mathrm{~nm}$ are obtained from the Agave Angustifolia plant ${ }^{24}$. In the case of Sisal, the diameter of the nanofibers is larger, ranging between $18 \mathrm{~nm}$ and $42 \mathrm{~nm}^{35}$.

\subsection{FTIR spectroscopy}

FTIR spectroscopic analysis of the raw and chemically treated Cereus Forbesii bark is presented in Figure 3. All spectra exhibited a broad band in the region between 3600 $\mathrm{cm}^{-1}$ and $3100 \mathrm{~cm}^{-1}$ associated with the free O-H stretch vibration of the $\mathrm{OH}$ group in cellulose molecules. In addition, all spectra show the C-H stretch vibration around 2900 $\mathrm{cm}^{-156}$. The differences between the spectra are attributed to changes in the composition of the sample that occurred during chemical treatments.

The FTIR spectrum corresponding to the raw bark shows peaks associated with lignin, hemicellulose, and cellulose (figure 3a). The FTIR peak at $1735 \mathrm{~cm}^{-1}$ is related to the $\mathrm{C}=\mathrm{O}$ stretching vibration of the acetyl and uronic ester groups of hemicelluloses, and/or the ester linkage of the carboxylic group of the lignin and/or hemicellulose ${ }^{57}$, ${ }^{58}$. The IR vibration region between $1670 \mathrm{~cm}^{-1}$ to $1590 \mathrm{~cm}^{-1}$ can be attributed to the $\mathrm{O}-\mathrm{H}$ bending of the absorbed water ${ }^{59}$ and to the $\mathrm{C}=\mathrm{O}$ stretch vibration of the lignin aromatic skeleton ${ }^{60}$. On the other hand, the IR vibration region between $1510 \mathrm{~cm}^{-1}$ and $1460 \mathrm{~cm}^{-1}$ is associated with $\mathrm{C}-\mathrm{H}$ vibrations and deformations. Other peaks related to lignin appear at $1370 \mathrm{~cm}^{-1}, 1320 \mathrm{~cm}^{-1}$, and $1247 \mathrm{~cm}^{-1} 59,60$. The FTIR peak at $1375 \mathrm{~cm}^{-1}$ is related to the bending vibration of the $\mathrm{C}-\mathrm{H}$ and $\mathrm{C}-\mathrm{O}$ bond in the polysaccharide aromatic rings ${ }^{61}$, and the IR vibration at $1057 \mathrm{~cm}^{-1}$ is associated with the skeletal vibration of the pyranose ring $\mathrm{C}-\mathrm{O}-\mathrm{C}^{62}$. An FTIR vibration

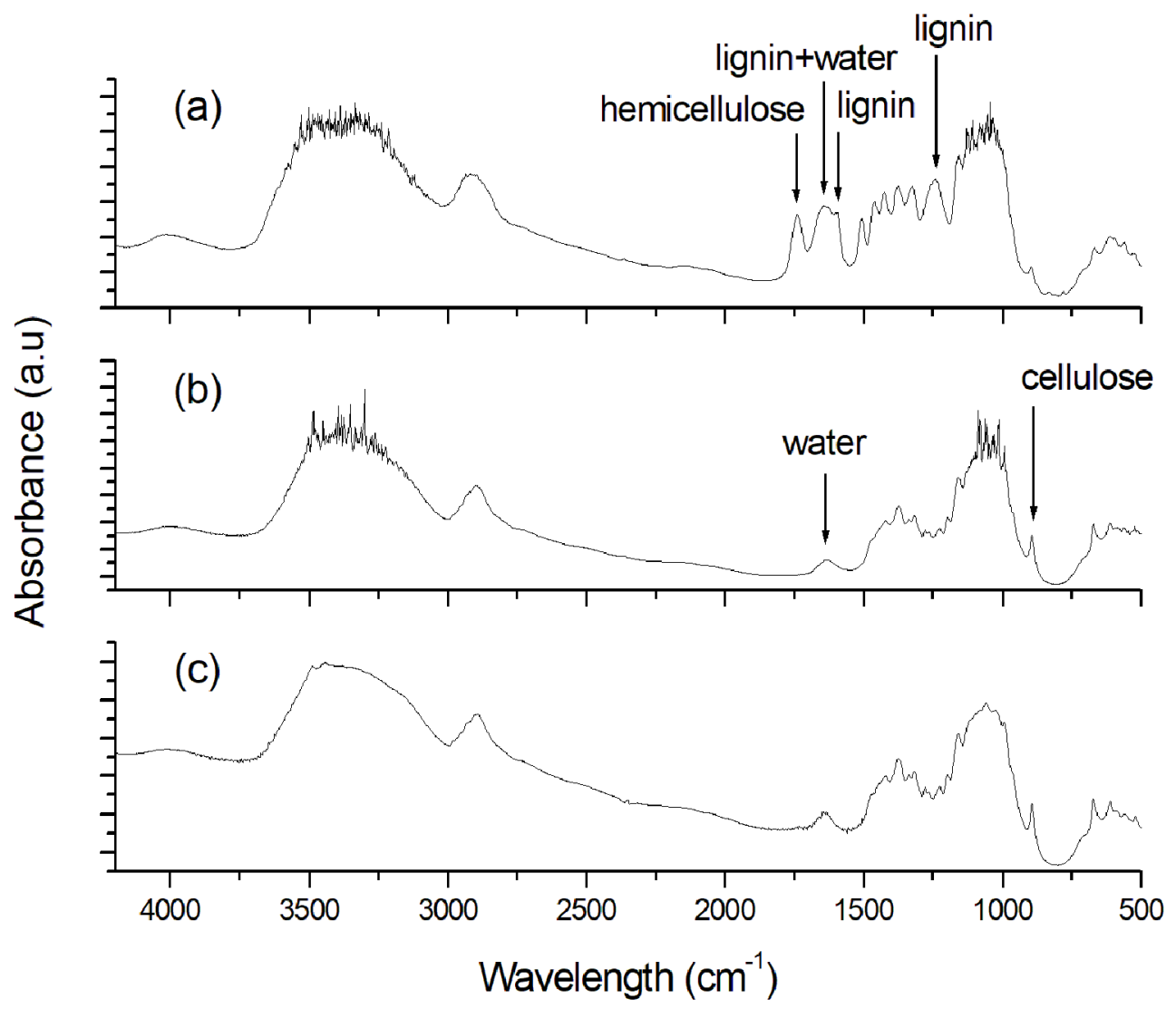

Figure 3. FTIR spectra of: Cereus Forbesii bark (a), cellulose obtained by alkaline treatment (b), and cellulose nanofibers obtained by the acid hydrolysis of cellulose (c). 
associated with cellulose appears at $895 \mathrm{~cm}^{-1}$. Such infrared vibration is related to the glycosidic $\mathrm{C}-\mathrm{H}$ deformation and the $\mathrm{O}-\mathrm{H}$ bending vibration ${ }^{30,31}$.

FTIR spectra change after chemical processing of the sample (see Figures $3 \mathrm{~b}$ and $3 \mathrm{c}$ ). The spectrum corresponding to cellulose nanofibers (Figure 3c) shows an increase in the crystallinity of the sample. The peaks associated with lignin and hemicellulose almost disappear completely when the chemical treatment is performed. There are more similarities than differences between the spectra recorded in figure $3 \mathrm{~b}$ and $3 \mathrm{c}$. The spectrum of the cellulose sample and the spectrum corresponding to crystalline cellulose nanofibers show similar peaks in all wave numbers because both samples are mainly composed of cellulose, the only difference is the change in the relative intensity of the peaks. It is possible to analyze the crystallinity of the sample through the evolution of the band at $895 \mathrm{~cm}^{-1}$ associated with cellulose. This band increases its relative intensity as the crystallinity of the sample increases.

\section{$3.3 X$-ray diffraction}

Figure 4 shows the X-ray diffraction patterns corresponding to the raw bark of Cereus Forbesii, the cellulose obtained by alkaline treatment and the cellulose nanofibers obtained by the acid hydrolysis of the cellulose.
All XRD patters exhibit peaks associated with crystalline cellulose. The intensity ratio of such peaks is different in each sample. These differences are associated with a phase transformation of cellulose as a result of chemical treatment and changes in the crystallinity of the samples. The hkl indexes corresponding to the main reflections of each crystalline phase are indicated.

There are several polymorphs of crystalline cellulose (I $\alpha$, I $\beta$, II, III, IV) ${ }^{63}$. Cellulose I $\alpha$ (triclinic structure) ${ }^{64}$ and I $\beta$ (monoclinic structure) ${ }^{65}$ are the crystalline celluloses produced naturally by living organisms. These two polymorphs coexist in several proportions depending on the source of cellulose ${ }^{23,63,66}$. The I $\alpha$ structure is the dominate polymorph for algae and bacteria, while the I $\beta$ phase is dominant for plant and tunicates ${ }^{3,67}$. The I $\alpha$ and I $\beta$ structures are metastable, and can be transformed into cellulose II by hydrothermal treatments in alkaline solution ${ }^{68}$. Such phase transformation is registered for the studied samples. Cellulose $\mathrm{I} \beta$ is the main crystalline component of the raw bark of Cereus Forbesii (figure 4a), while cellulose II is the crystalline phase of the crystalline domains of the cellulose obtained by alkaline treatment (figure 4b), and of the cellulose nanofibers obtained by the acid hydrolysis of cellulose (figure 4c).
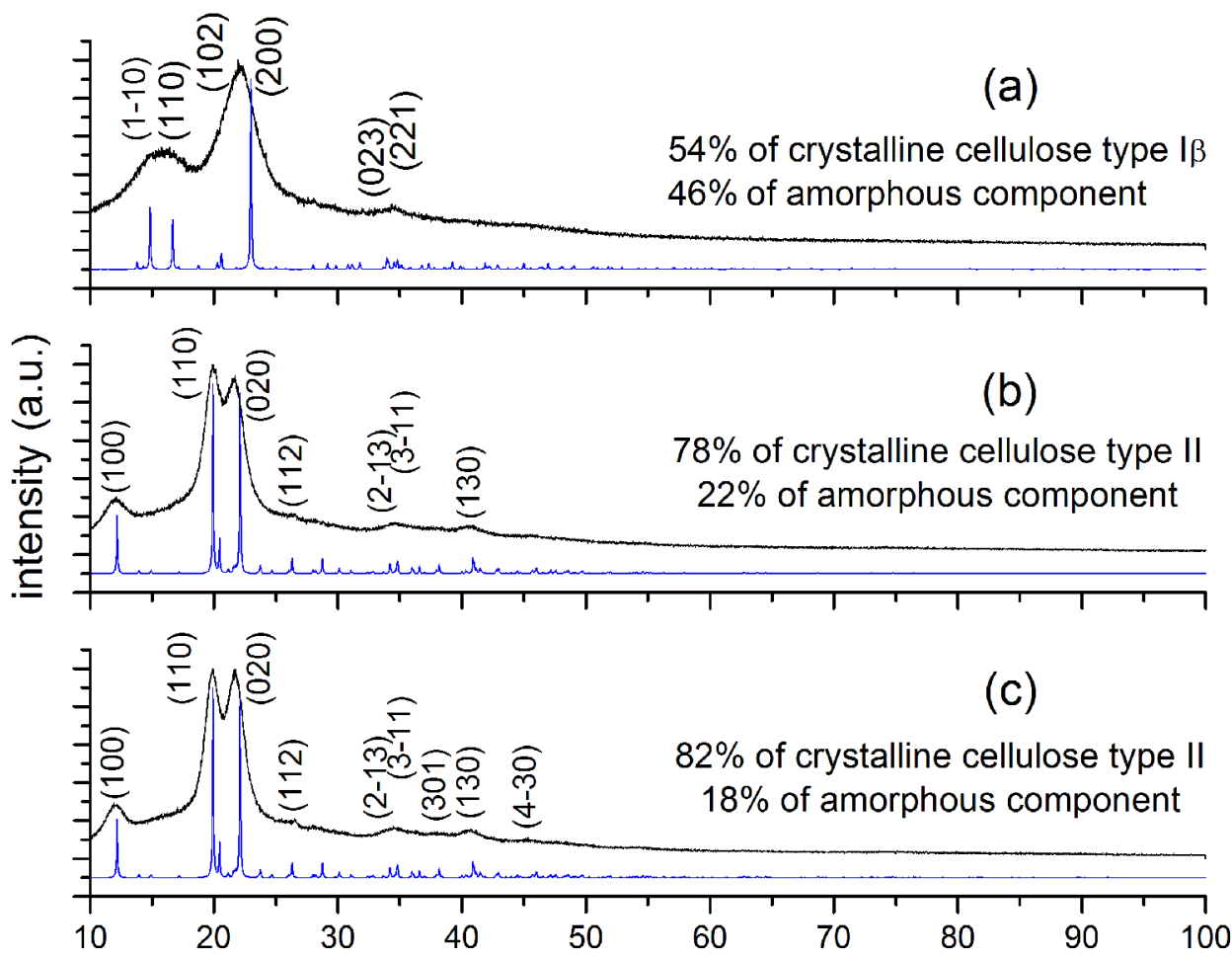

$2 \theta\left({ }^{\circ}\right)$

Figure 4. XRD patterns corresponding to: raw bark of Cereus Forbesii (a), cellulose obtained by alkaline treatment (b), and cellulose nanofibers obtained by the acid hydrolysis of cellulose (c). The main indices (h k l) corresponding to the reflections of the crystalline phases are indicated. The calculated XRD patterns of cellulose type I ${ }^{65}$ and cellulose type II ${ }^{69}$ are showed. 
The XRD pattern corresponding to the bark of Cereus Forbesii shows low crystallinity. The X-ray pattern of that sample indicates a crystalline disorder, evidenced by a high background and widened peaks. Only three broad peaks are observed due to the presence of amorphous material which covers most of the reflections corresponding to the crystalline structure of cellulose I $\beta$. Crystallinity increases when lignin, hemicellulose and other amorphous components are almost completely removed during chemical treatment. The XRD patterns corresponding to cellulose obtained by alkaline treatment (figure $4 \mathrm{~b}$ ) and cellulose nanofibers (CNF) obtained by the acid hydrolysis of cellulose (figure 4c) show more intense and narrower crystalline peaks. The XRD pattern of cellulose nanofibers shows an increase in the intensity of all peaks with respect to the XRD pattern of cellulose (the intensity of the (020) maximum increases $12 \%$ ). Such behavior indicates a change in the crystallinity of the samples and can be quantified by the crystallinity index.

The crystallinity index (Ic) of all samples is calculated using the peak height method (equation 1) ${ }^{53,54}$.

$$
I c=\frac{I \max -I a m}{I \max } .100
$$

In this equation, where $I c$ expresses the relative degree of crystallinity, Imax is the maximum intensity (in arbitrary units) of the most intense peak of the crystalline contribution, and Iam is the intensity of diffraction that represents the amorphous component (without crystalline diffraction). $\mathrm{X}$-ray diffraction patterns show that the possible values for the determination of amorphous content are the intensity at $18.26^{\circ}$ for cellulose I $\beta$ (figure $4 \mathrm{a}$ ) and the intensity at $14^{\circ}$ for cellulose II (figure $4 \mathrm{~b}$ and figure $4 \mathrm{c}$ ).

The calculated values of $I c$ are: $54 \%$ for the raw bark of Cereus Forbesii, 78\% for the cellulose obtained by alkaline treatment, and $82 \%$ for the cellulose nanofibers (CNF) obtained by the acid hydrolysis of cellulose. The increase in the value of $I c$ is attributed to the elimination of amorphous constituents after chemical treatment, and to the rearrangement of cellulose crystalline domains in a more orderly structure. However, XRD pattern corresponding to the cellulose nanofibers shows a slight peaks broadening indicating crystal disorder. This may be due to the effect of crystallite size and the presences of some amorphous regions that remain in the CNF.

The analysis of the XRD pattern allows to determine the average size of the crystallites that form the cellulose nanofibers. Scherrer's formula (equation 2) can be used to estimate crystallite size $\left(\mathrm{L}_{\mathrm{hkl}}\right)^{70,71}$.

$$
L_{h k l}=\frac{0.9 \lambda}{\beta_{h k l} \cos \theta_{h k l}}
$$

This method is approximate. The term $\mathrm{L}_{\mathrm{hkl}}$ present in the Scherrer equation should be interpreted as an average of the dimensions of the crystal perpendicular to the diffraction plane. The (110) plane is parallel to the "c" axis and $\mathrm{L}_{110}$ provides information on the crystallite diameter. The values of the peak width $(\beta)$ and the position $(\theta)$ of the (hkl) plane used in the Scherrer equation are determined by adjusting the XRD profile with a Lorentzian function. To subtract the experimental effects, the deconvolution of XRD peaks is performed by using standard NBS 640 silicon (certified standard). In equation $2 \lambda$ is the wavelength of the incident $\mathrm{X}$-ray radiation (1.4518 $\AA$ for $\mathrm{Cu}-\mathrm{K} \alpha$ radiation).

The Scherrer equation considers that the particles are spherical and stress free in the crystal lattice. When using the Scherrer approach, an average size of $6 \mathrm{~nm}$ was estimated for the crystallites that form the cellulose nanofibers. These values are similar to those reported for crystalline cellulose nanoparticles obtained from sugarcane bagasse ${ }^{72}$, Agabe Angustifolia fibers ${ }^{24}$, coconut husk ${ }^{73}$, and Sisal fibers ${ }^{34,35}$.

\subsection{Thermogravimetric analysis}

Thermogravimetric analysis is used to study the thermal stability of the samples. The thermal behavior depends on the chemical composition of the sample, its structure and crystallinity ${ }^{74}$.

Figure 5 shows the thermogravimetric (TG) curves corresponding to the raw bark of Cereus Forbesii (a), the cellulose obtained by alkaline treatment (b) and the cellulose nanofibers obtained by the acid hydrolysis of the cellulose (c). Due to the differences in the chemical structures of hemicellulose, cellulose and lignin, there are differences between the thermogravimetric curve "a", and TG curves "b" and "c". Table 3 reports the thermal decomposition parameters of all samples.

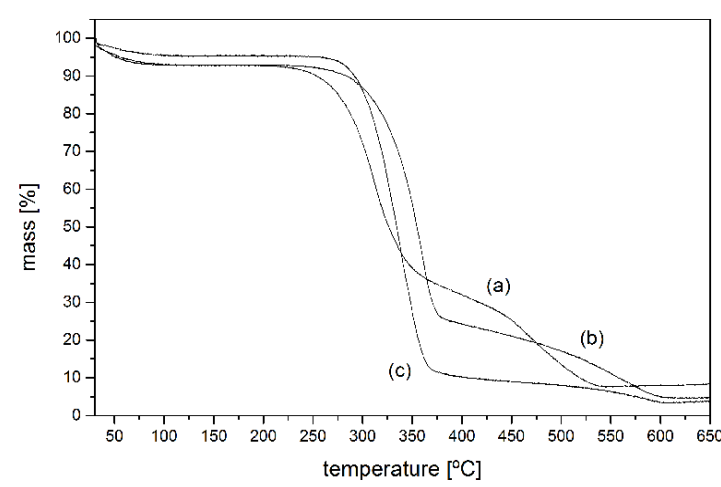

Figure 5. TG curves corresponding to: raw bark of Cereus Forbesii (a), cellulose obtained by alkaline treatment (b), and cellulose nanofibers obtained by the acid hydrolysis of cellulose (c).

All curves show a small weight loss associated with the evaporation of water (dehydration) between room temperature and $100^{\circ} \mathrm{C}$. The thermal decomposition of all samples shows weight losses that resulted in a final ash residue. Such residue is formed from $550^{\circ} \mathrm{C}$ for the raw bark (curve "a"), and from $600^{\circ} \mathrm{C}$ for the samples of cellulose and cellulose nanofibers (curves "b" and "c"). 
Table 3. Thermal decomposition parameters of the studied samples.

\begin{tabular}{ll}
\hline sample & degradation steps \\
\hline Cereus Forbesii bark & $\begin{array}{l}\text { room temperature }-100^{\circ} \mathrm{C}: \text { water } \\
\text { evaporation, weight loss of } 7.3 \%\end{array}$ \\
& $220^{\circ} \mathrm{C}-550^{\circ} \mathrm{C}:$ lignin, \\
& hemicellulose and cellulose \\
& decomposition, weight loss of $85 \%$ \\
& above $550^{\circ} \mathrm{C}: 7.7 \%$ of ash \\
& room temperature $-100^{\circ} \mathrm{C}:$ water \\
& evaporation, weight loss of $7.1 \%$ \\
& $220^{\circ} \mathrm{C}-375^{\circ} \mathrm{C}:$ cellulose \\
decomposition $($ amorphous and & \\
& crystalline components), weight loss \\
& of $66.1 \%$ \\
& $375^{\circ} \mathrm{C}-600^{\circ} \mathrm{C}:$ total degradation of \\
& crystalline cellulose polymer chains, \\
& weight loss of $21.9 \%$ \\
& above $600^{\circ} \mathrm{C}: 4.9 \%$ of ash \\
& room temperature $-100^{\circ} \mathrm{C}:$ water \\
& evaporation, weight loss of $4.8 \%$ \\
& $290^{\circ} \mathrm{C}-375^{\circ} \mathrm{C}:$ decomposition of \\
crystalline cellulose polymer chains, & weight loss of $86.1 \%$ \\
& $375^{\circ} \mathrm{C}-600^{\circ} \mathrm{C}:$ total degradation of \\
crystalline cellulose polymer chains, & weight loss of $5.7 \%$ \\
& above $600^{\circ} \mathrm{C}: 3.4 \%$ of ash \\
\hline cellulose nanofibers & \\
& \\
&
\end{tabular}

In the case of the raw bark, there are lignocellulosic materials that decompose with some temperature overlap. Hemicellulose and cellulose follow a similar pattern of decomposition, with somewhat lower activation and decomposition temperatures in the case of hemicellulose. The decomposition of lignin, hemicellulose and cellulose takes place between $220^{\circ} \mathrm{C}$ and $550^{\circ} \mathrm{C}$ for the raw bark sample. Above $550^{\circ} \mathrm{C}$, the TG curve shows a zero slope that indicates the end of material decomposition. In the case of lignin, there are reports of higher decomposition temperatures, for example $700^{\circ} \mathrm{C}$ for Sisal fibers ${ }^{35}$. This wide range of decomposition temperature is due to the different binding energies of the chemical bonds present in the sample structure ${ }^{75}$.

The thermogravimetric curves of the cellulose samples are similar (curves " $b$ " and "c"). The TG curves of these samples exhibit three weight losses associated with three stages of thermal decomposition. These stages are related to: water evaporation, cellulose decomposition, and total degradation of cellulose polymer chains. The first stage takes place between room temperature and $100^{\circ} \mathrm{C}$. The second weight loss occurs between the initial temperature of $220^{\circ} \mathrm{C}$ for the cellulose sample and $290^{\circ} \mathrm{C}$ for the cellulose nanofibers sample and a final temperature of $375^{\circ} \mathrm{C}$ for both samples. The last stages of decomposition take place between $375^{\circ} \mathrm{C}$ and $600^{\circ} \mathrm{C}$ for both samples. Above $600^{\circ} \mathrm{C}$ an ash residue is formed. Such temperature values are similar to those reported for thermal decomposition of cellulose obtained from other plant sources ${ }^{76-78}$.

The differences between the TG curves " $b$ " and "c" are due to the relative amount of amorphous and crystalline cellulose present in the samples. Such differences in the composition affect the crystallinity of the samples and, therefore, the profiles of the TG curves. In addition, in the case of the cellulose nanofiber sample (curve "c"), there is less water and less ash in relative percentage than in the case of the cellulose sample (curve "b"). Such behavior is associated with the crystallinity of the sample. The sample of cellulose nanofibers is formed almost entirely by polymer chains with a high crystalline order ( $82 \%$ of the sample). The high crystallinity of cellulose nanofibers makes the sample very homogeneous and decomposes in a relatively narrow temperature range (the second stage of decomposition of the TG curve).

\section{Conclusions}

Crystalline cellulose nanofibers were obtained from the bark of the Cereus Forbesii cactus. The obtaining of cellulose nanofibers was carried out in several steps: pretreatment of the raw material, elimination of hemicellulose and lignin to obtain cellulose, and an acid hydrolysis of cellulose to obtain crystalline cellulose nanofibers. The peaks associated with lignin and hemicellulose almost disappear completely when the chemical treatment is performed. Cellulose nanofibers with a crystallinity index of $82 \%$ are obtained. Cellulose nanofibers, composed of $6 \mathrm{~nm}$ nanocrystals of average size, have an average diameter of $18 \mathrm{~nm}$. These results are similar to those reported for cellulose nanofibers obtained from other plants. The high crystallinity of the obtained cellulose nanofibers makes the sample very homogeneous and decomposes in a relatively narrow temperature range (between $290^{\circ} \mathrm{C}$ and $375^{\circ} \mathrm{C}$ ). The complete degradation of crystalline cellulose polymer chains takes place between $375^{\circ} \mathrm{C}$ and $600^{\circ} \mathrm{C}$.

\section{Acknowledgements}

This work was supported by the National Scientific and Technical Research Council (CONICET) and the National Agency for Scientific and Technological Promotion of Argentine [PICTO-UNAF \#2014-0020].

\section{References}

1. Takagi H, Ichihara Y. Effect of fiber length on mechanical properties of "green" composites using a starch-based resin and short bamboo fibers. JSME International Journal Series A. 2004;47(4):551-555. DOI: https://doi.org/10.1299/jsmea.47.551

2. Takagi H, Asano A. Effects of processing conditions on flexural properties of cellulose nanofiber reinforced "green" composites. Composites Part A: Applied Science and Manufacturing. 2008;39(4):685-689. DOI: https://doi.org/10.1016/j. compositesa.2007.08.019 
3. Moon RJ, Martini A, Nairn J, Simonsen J, Youngblood J. Cellulose nanomaterials review: structure, properties and nanocomposites. Chemical Society Reviews. 2011;40(7):39413994. DOI: https://doi.org/10.1039/c0cs00108b

4. Sarwar MS, Niazi MBK, Jahan Z, Ahmad T, Hussain A. Preparation and characterization of PVA/nanocellulose/Ag Nanocomposite films for antimicrobial food packaging. Carbohydrate Polymers. 2018;184:453-464.

5. Ferrer A, Pal L, Hubbe M. Nanocellulose in packaging: advances in barrier layer technologies. Industrial Crops and Products. 2017;95:574-582.

6. Dufresne A. Cellulose nanomaterial reinforced polymer nanocomposites. Current Opinion in Colloid and Interface Science. 2017;29:1-8.

7. Kargarzadeh H, Mariano M, Huang J, Lin N, Ahmad I, Dufresne A, et al. Recent developments on nanocellulose reinforced polymer nanocomposites: a review. Polymer. 2017;132:368-393.

8. Nair SS, Zhu JY, Deng Y, Ragauskas AJ. High performance green barriers based on nanocellulose. Sustainable Chemical Processes. 2014;2(23):2-7.

9. Chen JP, Yang PC, Ma YH, Wu T. Characterization of chitosan magnetic nanoparticles for in situ delivery of tissue plasminogen activator. Carbohydrate Polymers. 2011;84(1):364-372. DOI: https://doi.org/10.1016/j.carbpol.2010.11.052

10. Zhou YT, Branford-White C, Nie HL, Zhu LM. Adsorption mechanism of $\mathrm{Cu}^{2+}$ from aqueous solution by chitosan-coated magnetic nanoparticles modified with $\alpha$-ketoglutaric acid. Colloids and Surfaces B: Biointerfaces. 2009;74(1):244-252. DOI: https://doi.org/10.1016/j.colsurfb.2009.07.026

11. Nata IF, Sureshkumar M, Lee CK. One-pot preparation of amine-rich magnetite/bacterial cellulose nanocomposite and its application for arsenate removal. RSC Advances. 2011;1(4):625-631. DOI: https://doi.org/10.1039/c1ra00153a

12. Aoki Y, Huang J, Kunitake T. Electro-conductive nanotubular sheet of indium tin oxide as fabricated from the cellulose template. Journal of Materials Chemistry. 2006;16(3):292297. DOI: https://doi.org/10.1039/b512225b

13. Zheng G, Cui Y, Karabulut E, Wågberg L, Zhu H, Hu L. Nanostructured paper for flexible energy and electronic devices. MRS Bulletin. 2013;38(4):320-325. DOI: https:// doi.org/10.1557/mrs.2013.59

14. Siqueira G, Bras J, Dufresne A. Cellulose whiskers versus microfibrils: influence of the nature of the nanoparticle and its surface functionalization on the thermal and mechanical properties of nanocomposites. Biomacromolecules. 2009;10(2):425-432. DOI: https://doi.org/10.1021/bm801193d

15. Nechyporchuk O, Belgacem MN, Bras J. Production of cellulose nanofibrils: a review of recent advances. Industrial Crops and Products. 2016;93:2-25. DOI: https://dx.doi.org/10.1016/j. indcrop.2016.02.016

16. Charreau H, Foresti L, Vazquez A. Nanocellulose patents trends: a comprehensive review on patents on cellulose nanofibrils, microfibrillated, and bacterial cellulose. Recent Patents on Nanotechnology. 2013;7(1):56-80. DOI: http://dx.doi. org/10.2174/187221013804484854
17. Bardet R, Bras J. Cellulose nanofibers and their use in paper industry. In: Oksman K, Mathew AP, Bismarck A, Rojas O, Sain M, editors. Handbook of Green Materials. River Edge, NJ: World Scientific; 2014. p. 207-232. DOI: http://dx.doi. org/10.1142/97898145664690013

18. Lindström T, Aulin C. Market and technical challenges and opportunities in the area of innovative new materials and composites based on nanocellulosics. Scandinavian Journal of Forest Research. 2014;29(4):345-351. DOI: http://dx.doi. org/10.1080/02827581.2014.928365

19. Benziman M, Haigler CH, Brown RM, White AR, Cooper KM. Cellulose biogenesis: polymerization and crystallization are coupled processes in Acetobacter xylinum. National Academy of Science USA. 1980;77(11):6678-82.

20. Itoh T, Brown Junior RM. The assembly of cellulose microfibrils in Valonia macrophysa. Planta. 1984;160(4):372-381.

21. Rong MZ, Zhang MQ, Lui Y, Yang GC, Zeng HM. The effect of fiber treatment on the mechanical properties of unidirectional sisal-reinforced epoxi composites. Composites Science and Technology. 2001;61(10):1437-1447.

22. Vignon MR, Heux L, Malainine ME, Mahrouz M. Arabinancellulose composite in Opuntia ficus-indica prickly pear spines. Carbohydrate Research. 2004;339(1):123-131.

23. Nishiyama Y. Structure and properties of the cellulose microfibril. Journal of Wood Science. 2009;55(4):241-249. DOI: https:// doi.org/10.1007/s10086-009-1029-1

24. Rosli NA, Ahmad I, Abdullah I. Isolation and characterization of cellulose nanofibrils from agave angustifolia fibre. BioResources. 2013;8(2):1893-1908. DOI: http://ojs.cnr.ncsu.edu/index.php/ BioRes/article/view/BioRes_08_2_1893_Rosli_Isolation_ Cellulose_Nanofibrils

25. Morais JPS, Rosa MF, Souza Filho MSM, Nascimento LD, Nascimento DM, Cassales A. Extraction and characterization of nanocellulose structures from raw cotton linter. Carbohydrate Polymers. 2003;91(1):229-235.

26. Leitner J, Hinterstoisser B, Wastyn M, Keckes J, Gindl W. Sugar beet cellulose nanofibril-reinforced composites. Cellulose. 2007;14(5):419-425. DOI: https://doi.org/10.1007/ s10570-007-9131-2

27. Cao X, Dong H, Li CM. New nanocomposite materials reinforced with flax cellulose nanofibrils in waterborne polyurethane. Biomacromolecules. 2007;8(3):899-904. DOI: https://doi. org $/ 10.1021 / \mathrm{bm} 0610368$

28. Ludueña L, Fasce D, Alvarez VA, Stefani PM. Nanocellulose from rice husk following alkaline treatment to remove silica. BioResources. 2011;6(2):1440-1453. DOI: https://doi. org/10.15376/biores.6.2.1440-1453

29. Zimmermann T, Bordeanu N, Strub E. Properties of nanofibrillated cellulose from different raw materials and its reinforcement potential. Carbohydrate Polymers. 2010;79(4):1086-1093. DOI: https://doi.org/10.1016/j.carbpol.2009.10.045

30. Alemdar A, Sain M. Biocomposites from wheat straw nanofibers: morphology, thermal and mechanical properties. Composites Science and Technology. 2008;68(2):557-565. DOI: https:// doi.org/10.1016/j.compscitech.2007.05.044 
31. Alemdar A, Sain M. Isolation and characterization of nanofibers from agricultural residues - wheat straw and soy hulls. Bioresource Technology. 2008;99(6):1664-1671. DOI: https:// doi.org/10.1016/j.biortech.2007.04.029

32. Dufresne A, Dupeyre D, Vignon MR. Cellulose microfibrils from potato tuber cells: processing and characterization of starch - cellulose microfibril composites. Journal of Applied Polymer Science. 2000;76(14):2080-2092. https://doi. org/10.1002/(SICI)1097-4628(20000628)76:14<2080::AIDAPP12>3.0.CO;2-U

33. Zuluaga R, Putaux JL, Restrepo A, Mondragon I, Gañán P. Cellulose microfibrils from banana farming residues: Isolation and characterization. Cellulose. 2007;14:585-592. DOI: https:// doi.org/10.1007/s10570-007-9118-z

34. Rodriguez NLG, Thielemans W, Dufresne A. Sisal cellulose whiskers reinforced polyvinyl acetate nanocomposites. Cellulose. 2006;13:261-270. DOI: https://doi.org/10.1007/s10570-005-9039-7

35. Juan IM, Alvarez VA, Viviana PC, Analia V. Extraction of cellulose and preparation of nanocellulose from sisal fibers. Cellulose. 2008;15:149-159. https://doi.org/10.1007/s10570007-9145-9

36. Neme G, Nieto M, D'Arcangblo AT, Gros E. 3-Nitro-4-hydroxyphenethylamine from Cereus Validus. Phytochemistry. 1977;16(2):277278. DOI: https://doi.org/10.1016/S0031-9422(00)86802-8

37. Nobel PS, Lüttge U, Heuer S, Ball E. Influence of applied $\mathrm{NaCl}$ on crassulacean acid metabolism and ionic levels in a cactus, Cereus validus. Plant Physiology. 1984;75:799-803. DOI: https://doi.org/10.1104/pp.75.3.799

38. Souza Filho PF, Ribeiro VT, Santos ES, Macedo GR. Simultaneous saccharification and fermentation of cactus pear biomassevaluation of using different pretreatments. Industrial Crops and Products. 2016;89:425-433. DOI: https://doi.org/10.1016/j. indcrop.2016.05.028

39. Cranston ED, Gray DG. Morphological and optical characterization of polyelectrolyte multilayers incorporating nanocrystalline cellulose. Biomacromolecules. 2006;7(9):2522-2530. DOI: https://doi.org/10.1021/bm0602886

40. Habibi Y, Lucia LA, Rojas OJ. Cellulose nanocrystals: chemistry, self-assembly, and applications. Chemical Re. 2010;110(6):34793500. DOI: https://doi.org/10.1021/cr900339w

41. Hubbe MA, Rojas OJ, Lucia LA, Sain M. Cellulosic nanocomposites: a review. BioResources. 2008;3(3):929-980. DOI: https://doi. org/10.15376/biores.3.3.929-980

42. Marin DC, Vecchio A, Ludueña LN, Fasce D, Alvarez VA, Stefani PM. Revalorization of rice husk waste as a source of cellulose and silica. Fibers and Polymers. 2015;16(2):285-293. DOI: https://doi.org/10.1007/s12221-015-0285-5

43. Siró I, Plackett D. Microfibrillated cellulose and new nanocomposite materials: a review. Cellulose. 2010;17(3):459-494. DOI: https://doi.org/10.1007/s10570-010-9405-y

44. Sluiter A, Ruiz R, Scarlata C, Sluiter J, Templeton D. Determination of extractives in biomass. National Renewable Energy Laboratory (U.S. Department of Energy). Laboratory Analytical Procedure. Colorado: Technical Report NREL/ TP-510-42619; 2005.
45. Sluiter A, Hames B, Ruiz R, Scarlata C, Sluiter J, Templeton D. Determination of Ash in Biomass. National Renewable Energy Laboratory (U.S. Department of Energy). Laboratory Analytical Procedure. Colorado: Technical Report NREL/ TP-510-42622; 2005.

46. Sluiter A, Hames B, Hyman D, Payne C, Ruiz R, Scarlata $\mathrm{C}$, et al. Determination of total solids in biomass and total dissolved solids in liquid process samples. National Renewable Energy Laboratory (U.S. Department of Energy). Laboratory Analytical Procedure. Colorado: Technical Report NREL/ TP-510-42621; 2008.

47. Sluiter A, Hames B, Ruiz R, Scarlata C, Sluiter J, Templeton $\mathrm{D}$, et al. Determination of Structural Carbohydrates and Lignin in Biomass. National Renewable Energy Laboratory (U.S. Department of Energy). Laboratory Analytical Procedure. Colorado: Technical Report NREL /TP-510-42618; 2011

48. Rodríguez MD, Paiva IMA, Castrillo ML, Zapata PD, Villalba LL. $\mathrm{KH}_{2} \mathrm{PO}_{4}$ improves cellulase production of Irpex lacteus and Pycnoporus sanguineus. Journal of King Saud University -Science. 2018;31(4):434-444. DOI: https://doi.org/10.1016/j. jksus.2018.07.009

49. Sun W, Othman MZ. A selective fractionation method of lignocellulosic materials using electro-assisted organosolv pretreatment. Bioresource Technology. 2019;288:121421. DOI: https://doi.org/10.1016/j.biortech.2019.121421

50. Liu H, Chen X, Ji G, Yu H, Gao C, Han L, et al. Mechanochemical deconstruction of lignocellulosic cell wall polymers with ballmilling. Bioresource Technology. 2019;286:121364. DOI: https://doi.org/10.1016/j.biortech.2019.121364

51. Toscan A, Fontana RC, Andreaus J, Camassola M, Lukasik RM, Dillon AJP. Bioresource Technology. 2019;285:121346. DOI: https://doi.org/10.1016/j.biortech.2019.121346

52. Souza Filho PF, Ribeiro VT, Santos ES, Macedo GR. Simultaneous saccharification and fermentation of cactus pearbiomass - evaluation of using different pretreatments. Industrial Crops and Products. 2016;89:425-433. DOI: http:// dx.doi.org/10.1016/j.indcrop.2016.05.028

53. LeCorre D, Vahanian E, Dufresne A, Bras J. Enzymatic pretreatment for preparing starch nanofibrils. Biomacromolecules. 2012;13(1):132-137. DOI: https://doi.org/10.1021/bm201333k

54. Segal L, Creely JJ, Martin Junior AE, Conrad CM. An empirical method for estimating the degree of crystallinity of native cellulose using the X-ray diffractometer. Textile Research Journal. 1959;29(10):786-794. https://doi. org/10.1177/004051755902901003

55. Stokes AR, Wilson AJC. The diffraction of X rays by distorted crystal aggregates - I. Proceedings of the Physical Society. 1944;56:174-181. DOI: https://doi.org/10.1088/0959$5309 / 56 / 3 / 303$

56. Khalil HPSA, Ismail H, Rozman HD, Ahmad MN. The effect of acetylation on interfacial shear strength between plant fibres and various matrices. European Polymer Journal. 2001;37(5):1037-1045. DOI: https://doi.org/10.1016/S00143057(00)00199-3 
57. Sun XD, Xu F, Sun RC, Fowler P, Baird MS. Characteristics of degraded cellulose obtained from steam-exploded wheat straw. Carbohydrate Research. 2005;340(1):97-106. DOI: https://doi.org/10.1016/j.carres.2004.10.022

58. Sain M, Panthapulakkal S. Bioprocess preparation of wheat straw fibers and their characterization. Industrial Crops and Products. 2006;23(1):1-8. DOI: https://doi.org/10.1016/j.indcrop.2005.01.006

59. Le Troedec M, Sedan D, Peyratout C, Bonnet JP, Smith A, Guinebretiere R, et al. Influence of various chemical treatments on the composition and structure of hemp fibres. Composites Part A: Applied Science and Manufacturing. 2008;39(3):514522. DOI: https://doi.org/10.1016/j.compositesa.2007.12.001

60. Jahan MS, Chowdhury DAN, Islam MK, Moeiz SMI. Characterization of lignin isolated from some nonwood available in Bangladesh. Bioresource Technology. 2007;98(2):465-469. DOI: https://doi.org/10.1016/j.biortech.2006.01.005

61. Nacos MK, Katapodis P, Pappas C, Daferera D, Tarantilis PA, Christakopoulos P, et al. Kenaf xylan - a source of biologically active acidic oligosaccharides. Carbohydrate Polymers. 2006;66(1):126-134. DOI: https://doi.org/10.1016/j. carbpol.2006.02.032

62. Elanthikkal S, Gopalakrishnapanicker U, Varghese S, Guthrie JT. Cellulose microfibres produced from banana plant wastes: isolation and characterization. Carbohydrate Polymers. 2010;80(3):852859. DOI: https://doi.org/10.1016/j.carbpol.2009.12.043

63. O'Sullivan AC. Cellulose: the structure slowly unravels. Cellulose. 1997;4:173-207. DOI: https://doi.org/10.1023/A:1018431705579

64. Nishiyama Y, Sugiyama J, Chanzy H, Langan P. Crystal structure and hydrogen bonding system in cellulose I $\alpha$ from synchrotron $\mathrm{x}$-ray and neutron fiber diffraction. Journal of the American Chemical Society. 2003;125(47):14300-14306. DOI: https:// doi.org/10.1021/ja037055w

65. Nishiyama Y, Sugiyama J, Chanzy H. Crystal structure and hydrogen-bonding system in cellulose I $\beta$ from synchrotron $\mathrm{X}$-ray and neutron fiber diffraction. Journal of the American Chemical Society. 2002;124(31):9074-9082. DOI: https://doi. org/10.1021/ja0257319

66. Samir MAS, Alloin F, Dufresne A. Review of recent research into cellulosic whisker, their properties and their application in nanocomposites field. Biomacromolecules. 2005;6(2):612626. https://doi.org/10.1021/bm0493685

67. Belton PS, Tanner SF, Cartier N, Chanzy H. High-resolution solid-state carbon-13 nuclear magnetic resonance spectroscopy of tunicin, an animal cellulose. Macromolecules. 1989;22(4):16151617. DOI: https://doi.org/10.1021/ma00194a019
68. Klemm D, Heublein B, Fink HP, Bohn A. Cellulose: fascinating biopolymer and sustainable raw material. AngewandteChemie - International Edition. 2006;44(22):3358-3393. DOI: https:// doi.org/10.1002/anie.200460587

69. Langan P, Nishiyama Y, Chanzy H. X-ray structure of mercerized cellulose II at $1 \AA$ resolution. Biomacromolecules. 2001;2(2):410-416. DOI: https://doi.org/10.1021/bm005612q

70. Hall WH. X-ray line broadening in metals. Proceedings of the Physical Society. Section A. 1949;62(11):741-743. DOI: https://doi.org/10.1088/0370-1298/62/11/110

71. Klug HP, Alexander LE. X-Ray diffraction procedures: for polycrystalline and amorphous materials. New York: John Wiley \& Sons; 1956. v. 4. DOI: https://doi.org/10.1016/00016160(56)90124-9

72. Teixeira EM, Bondancia TJ, Teodoro KBR, Corrêa AC, Marconcini JM, Mattoso LHC. Sugarcane bagasse whiskers: extraction and characterizations. Industrial Crops and Products. 2011;33(1):63-66. DOI: https://doi.org/10.1016/j. indcrop.2010.08.009

73. Rosa MF, Medeiros ES, Malmonge JA, Gregorski KS, Wood DF, Mattoso LHC, et al. Cellulose nanowhiskers from coconut husk fibers: effect of preparation conditions on their thermal and morphological behavior. Carbohydrate Polymers. 2010;81(1):83-92. DOI: https://doi.org/10.1016/j. carbpol.2010.01.059

74. Fisher T, Hajaligol M, Waymack B, Kellogg D. Pyrolysis behavior and kinetics of biomass derived materials. Journal of Analytical and Applied Pyrolysis. 2002;62(2):331-349. DOI: https://doi.org/10.1016/S0165-2370(01)00129-2

75. Yang H, Yan R, Chen H, Lee DH, Zheng C. Characteristics of hemicellulose, cellulose and lignin pyrolysis. Fuel. 2007;86(1213):1781-1788

76. Cheng KC, Catchmark JM, Demirci A. Effect of different additives on bacterial cellulose production by Acetobacter xylinum and analysis of material property. Cellulose. 2009;16(6):1033-1045. DOI: https://doi.org/10.1007/s10570-009-9346-5

77. Hassan-Nejad M, Ganster J, Bohn A, Pinnow M, Volkert B. Bio-based nanocomposites of cellulose acetate and nanoclay with superior mechanical Properties. Macromolecular Symposia. 2009;280(1):123-129. DOI: https://doi.org/10.1002/ masy.200950614

78. Petersson L, Kvien I, Oksman K. Structure and thermal properties of poly(lactic acid)/cellulose whiskers nanocomposite materials. Composites Science and Technology. 2007;67(11-12):25352544. DOI: https://doi.org/10.1016/j.compscitech.2006.12.012 